Portland State University

PDXScholar

1984

\title{
A longitudinal study of recidivism for 88 Forest Camp inmates
}

Loreli S. Manning

Portland State University

Follow this and additional works at: https://pdxscholar.library.pdx.edu/open_access_etds

Part of the Criminology Commons, Criminology and Criminal Justice Commons, and the Psychology Commons

Let us know how access to this document benefits you.

\section{Recommended Citation}

Manning, Loreli S., "A longitudinal study of recidivism for 88 Forest Camp inmates" (1984). Dissertations and Theses. Paper 3358.

https://doi.org/10.15760/etd.5242

This Thesis is brought to you for free and open access. It has been accepted for inclusion in Dissertations and Theses by an authorized administrator of PDXScholar. Please contact us if we can make this document more accessible: pdxscholar@pdx.edu. 
AN ABSTRACT OF THE THESIS OF Loreli s. Manning for the Master of Science in Psychology presented May 14, 1984.

Title: A Longitudinal study of Recidivism for 88 Forest Camp Inmates.

APPROVED BY MEMBERS OF THE THESIS COMMITTEE:

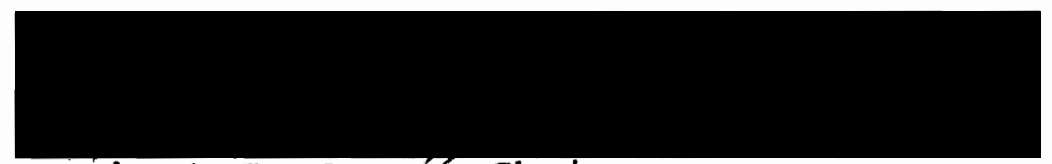

Robert E. Jones, Chairman

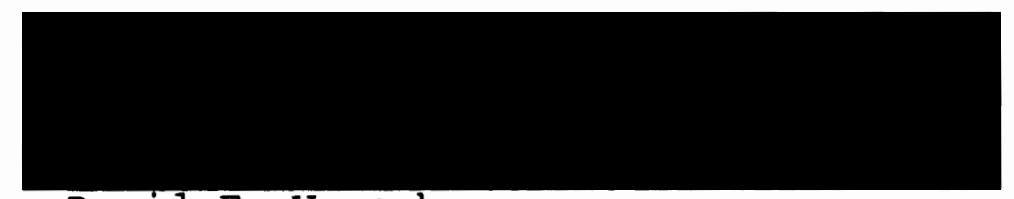

David F. Wrench
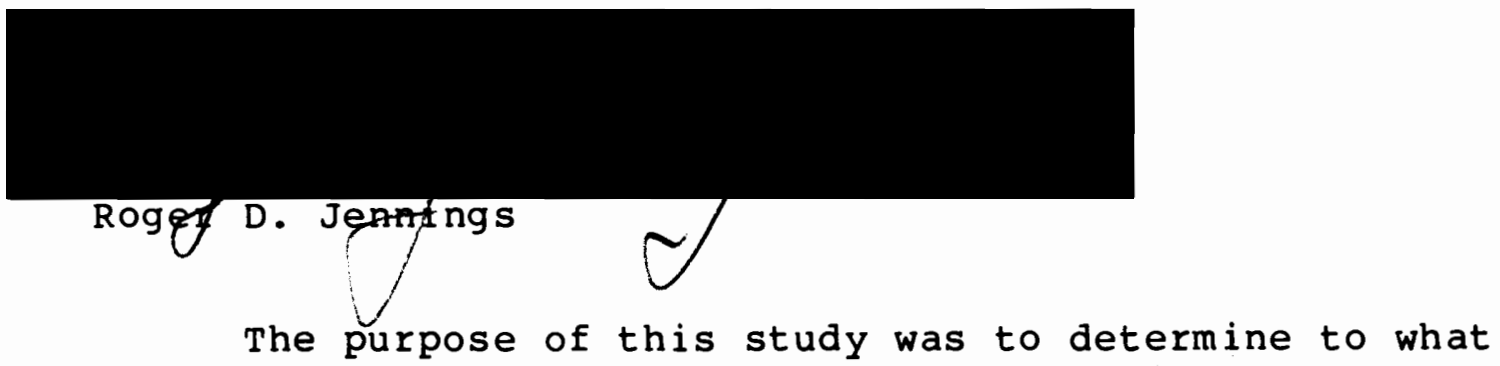
extent a group of 88 subjects, who were sentenced to the Forest Camp in the early seventies, remained law abiding in the ten years which followed their release. In addition to analyzing recidivist patterns, the study attempted to identify which variables were associated with subsequent recidivist and non-recidivist behavior and relate those findings to previous studies in the literature. 
Subjects in this study were classified as recidivists (failures) or non-recidivists (successes) utilizing the criteria of no subsequent convictions upon release from the Forest Camp, for which a jail or prison term was imposed. These criteria are consistent with those established in other research in the literature (England, 1955; Moberg, 1972; Mandel et al, 1965; Brown, 1978). All of these studies agree that conviction and subsequent confinement are the most definitive criteria of recidivism.

of the 88 subjects, 37 had one or more convictions for which they were sentenced to either jail or prison; while 51 had remained law abiding for a $1 \emptyset$ - 12 year period. Thus, the recidivism rate for this group of subjects was $42 \%$.

of the 37 recidivist subjects, 18 had not had a conviction within the last five years. In addition, 26 (7ø\%) of the recidivist group successfully completed the probationary period which followed their release from the Forest Camp. Therefore, most of the recidivist activity occurred in a time period immediately following termination of probation.

The second part of the analysis compared the personal characteristics and criminal history for a subset of 47 subjects for whom complete files could be located. Of the 47 subjects, 20 met the criteria of recidivist and 27 were nonrecidivist. Both univariate and multivariate techniques were utilized to test for differences between the two groups. The univariate analysis showed that the groups differed signifi- 
cantly on only two variables; marital status and parents economic status. However, when the multivariate technique of stepwise discriminant analysis was applied, the discriminant model which emerged contained five variables which discriminated between the recidivist and non-recidivist groups. These were: 1) Age at time sent to the Forest Camp; 2) Number of prior arrests; 3 ) Number of prior convictions; 4) Personality disorder; and 5) Drug use.

Therefore, the non-recidivist group could be generally differentiated from the recidivist group in that they were: 1) Younger by an average age of 21.6 months when entering the Forest Camp; 2) Had a lesser degree of criminal history than the recidivist group, as measured by the number of prior arrests and convictions, but had $18 \%$ more convictions per prior arrest than did the recidivist group; 3) Had more involvement with drugs, but fewer instances of documented personality disorders. In addition, the non-recidivist group served sentences which were on the average one-third longer than the recidivist subjects. The longer sentences appear to have had some degree of effectiveness particularly if drug use was involved. 


\title{
A LONGITUDINAL STUDY OF RECIDIVISM
}

\section{FOR 88 FOREST CAMP INMATES}

By

Loreli S. Manning

A thesis submitted in partial fulfillment of the requirements for the degree of

\author{
MASTER OF SCIENCE \\ in \\ PSYCHOLOGY
}

Portland State University

1984 
TO THE OFFICE OF GRADUATE STUDIES AND RESEARCH:

The members of the Committee approve the thesis of Loreli S. Manning presented May 14, 1984.

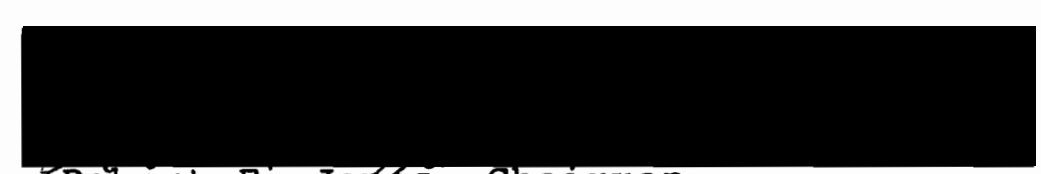

Robert E. Jobes, Chairman

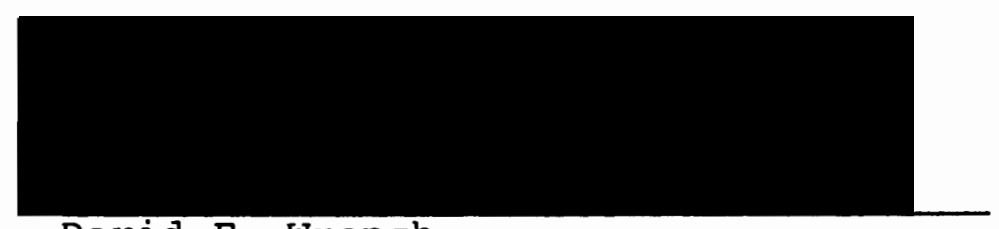

David F. Wrench

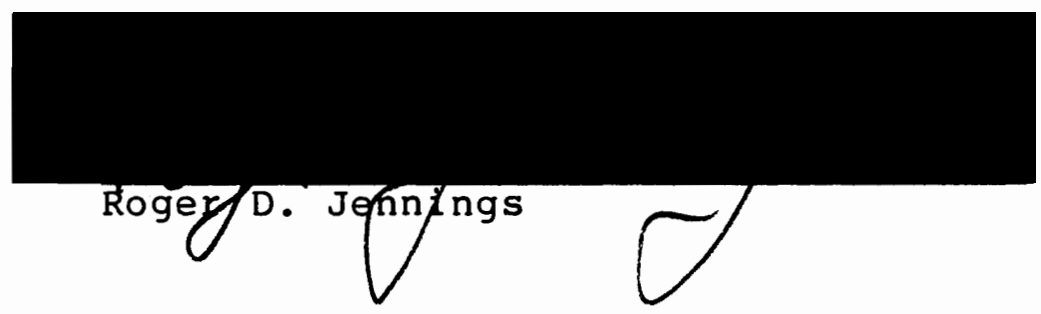

APPRQVED :

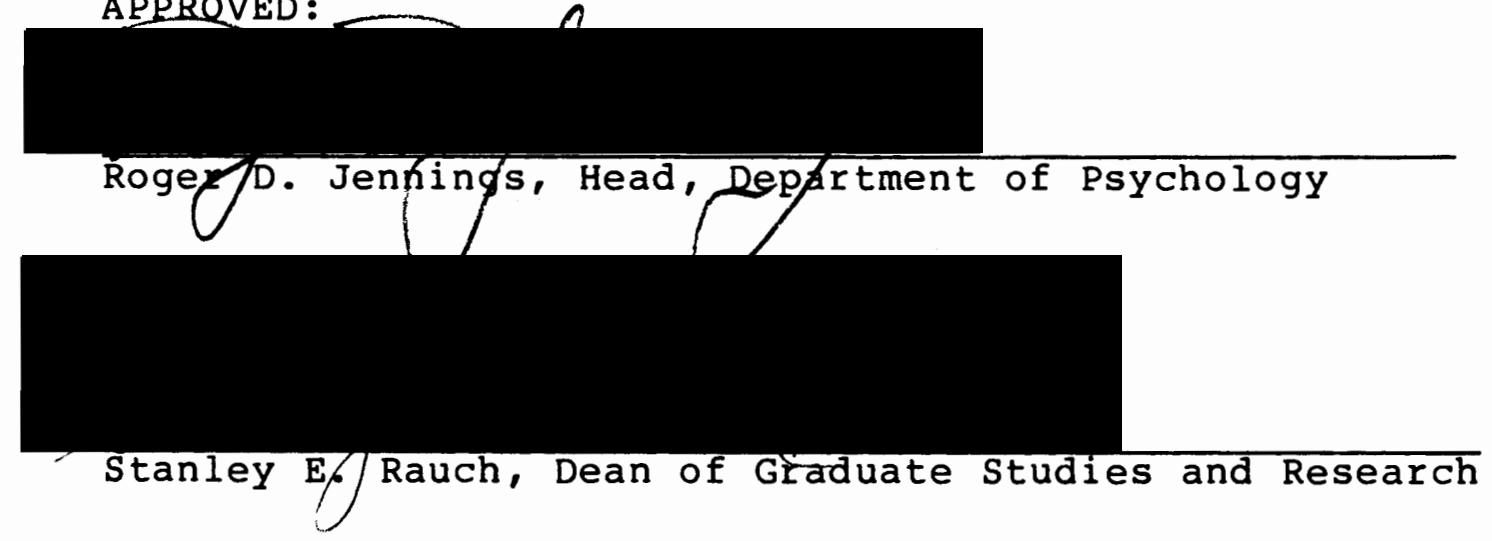


AC KNOWLEDGEMENTS

This research effort was supported and guided by two individuals who, coincidentally, bear the same name: Oregon supreme Court Justice Robert E. Jones, who $1 \emptyset$ years ago conceived the need for the study; and, throughout its duration, provided access to data and records as they were needed; and Dr. Robert E. Jones, Jr. Professor of Psychology, Portland State University, who served as my graduate advisor and thesis chairman.

In addition, I would like to thank:

John Amond who, as my employer, provided me with the maximum amount of flexibility in my work assignments so that I was able to pursue my graduate studies and completion of this thesis; Dr. David Wrench for bringing focus to the research and providing ongoing encouragement during the final months of the project; Dr. Roger Jennings for review, editing and overall direction; Chuck Bernard, Multnomah County Circuit Court Criminal Coordinator, for data retrieval; Carol Golding for programming support; Tektronix for use of their computer facilities; and Corina kizzar for typing and formatting the manuscript .

Finally, there are friends and family who helped me in a variety of ways and I'd like to thank all of them, too. 
TABLE OF CONTENTS

PAGE

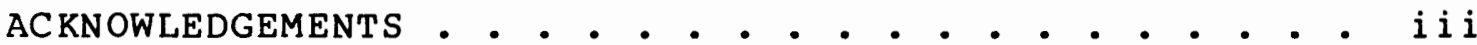
LIST OF TABLES • • • • • • • • • • • • • • • • • • • LIST OF FIGURES

CHAPTER

I INTRODUCTION

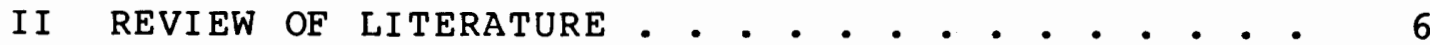

III DESCRIPTION OF PROBLEM •

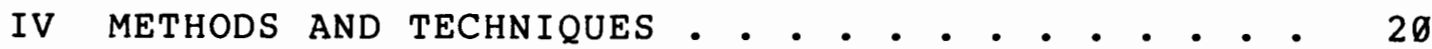

$\mathrm{V}$ RESULTS • • • • • • • • • • • • • • • • 27

VI DISCUSSION

REFERENCES • • • • • • • • • • • • • • • • • • • •

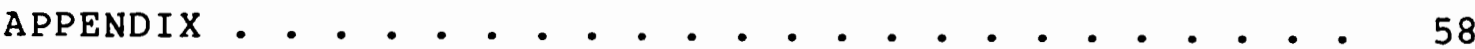




\section{LIST Of TABLES}

TABLE

PAGE

I. Patterns of Recidivist Group . . . . . . . . .

II. Sentences Imposed on Recidivist Group . . . . . .

II. Comparison of Past Release Involvement in

Criminal Justice System for Recidivist

and Non-Recidivist Groups . . . . . . . . . .

IV. Univariate Analysis of Variables Significant

at the 5 Percent Level or Less . . . . . . .

V. Univariate Analysis of Variables Not Significant at the 5 percent Level . . . . . . . . . . 38

VI. Discriminant Function Coefficients . . . . . . .

VII. Simple Correlation Coefficients Between

Discriminating Variables . . . . . . . . . . .

VIII. Classification Results Using Discriminant Model.

IX. Plot of Discriminant Scores . . . . . . . . . 


\section{LIST OF FIGURES}

FIGURE

PAGE

I. Decision Making Points in Criminal

Justice System . . . . . . . . . . . . . . 4

II. Time Elapsed Before First New Conviction . . . . 28 


\section{CHAPTER I}

\section{INTRODUCT ION}

The Forest Camp is a minimum security facility, located near Tillamook, Oregon, which is operated by the state Corrections Division. It is similar to a Civilian Conservation Camp of the late 1930's and provides a rugged, out-of-doors atmosphere where inmates work under the supervision of the oregon Forestry Department in varied areas of forest management: tree planting, trail building and fire fighting in season. It accommodates a maximum of $7 \emptyset$ men and is essentially operated as an honor facility. There is a strong emphasis on developing meaningful work habits and self reli ance.

The Forest Camp has been primarily utilized as a transitional facility between prison and parole. It has often been perceived as a "reward" for those who exhibit exemplary behavior while confined in prison. However, the inmate who would avoid strenuous physical labor often requests transfer back to a conventional institutional environment.

For approximately an 18 month period during 1971 and 1972 Multnomah County Circuit Court judges, through a special 
arrangement with the State Department of Corrections, were able to sentence offenders directly to the Forest Camp. During this period of time the Forest Camp served as a sentencing alternative to the oregon state Correctional Institution or county jail for the offender who needed to be removed from society, but for whom a longer sentence in a conventional prison environment was inappropriate or unnecessary.

It is important to point out that oregon, like many other states, does not statutorily provide the judiciary with the latitude of exercising sentencing alternatives; but, rather, permits only two options: probation or commitment to the State Department of Corrections. The State Department of Corrections makes the program or housing decision for all individuals committed to their custody. Judges may make recommendations, but the State Department of Corrections is not bound to follow them.

Consequently, the judges utilized the Forest Camp as a sentencing alternative by imposing a probation sentence which had as a condition (of probation) that the offender serve a specific period of time at the Tillamook Forest Camp. After release from the Forest Camp, the offender remained on probation for a set period of time. This is still the manner by which most alternative sentencing is accomplished today in various states where state statute does not provide for judicial discretion for sentencing options. The decision- 
making point in the criminal justice system where alternative programs may be considered is depicted in Figure 1.

It is not the thrust of this paper to examine the erosion of judicial power in terms of sentence fixing. It should be pointed out, however, that the established legal framework has provided for less and less judicial discretion over the last 75 years (Foote, 1972). At the same time, the need for alternative sentencing has become greater.

The increased focus on sentencing alternatives in the last 10 years actually has its roots in the prison reform movement of the sixties. This was followed by the intervention of the Federal Courts in the seventies. The Federal Courts became involved in the areas of jail and prison management over the issues of overcrowding and antiquated facilities. The inmate law suits which were filed in the Federal Court generally argued that these conditions constituted "cruel and unusual punishment". The early decisions in the seventies which ruled in favor of the inmates resulted in increased numbers of overcrowding suits. Currently there are literally hundreds of jails and prisons under Federal court order to reduce and maintain population ceilings.

Further emphasis on the need for sentencing alternatives came after a landmark supreme Court case. In Tate v. Short U.S. 395 (1971), the supreme Court declared unconstitutional a law which imposed a jail term for 


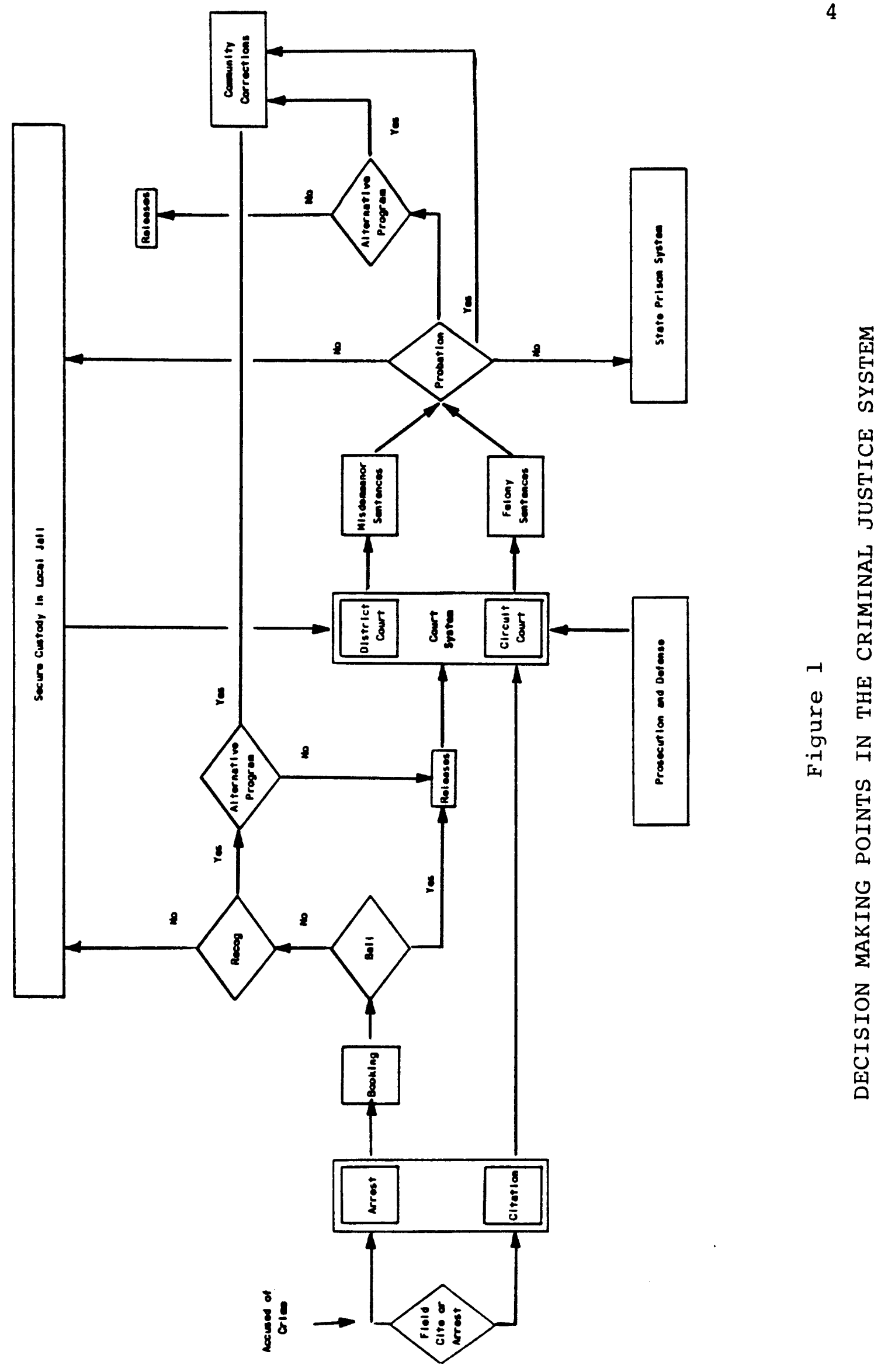


defendants who could not afford to pay their fines. This decision, which come to be known as the " $3 \emptyset$ days or $3 \emptyset$ dollars decision", effectively put conscientious judges into the role of community-service placement bureaus in search of appropriate sentencing alternatives. These events, in combination with shrinking resources at all levels of government, have forced a reappraisal of the objectives of imprisonment and the need for alternatives to prison. 
CHAPTER II

REVIEW OF THE LITERATURE

Most of the research on predicting an offender's viability for release into the community was generated because of the need to evaluate inmates' readiness for parole. In consequence this research was directed at identifying criteria which could predict the likelihood that a released inmate would recidivate. 1

Predicting future criminal behavior cannot be regarded as an easy task. As Barnes and Teiters (1959) point out, when all criminals are considered, those not apprehended as well as those arrested and convicted, "the criminal class as a whole is certainly as intelligent and stable, mentally and emotionally, as the general population" (p. 63).

The initial research on predictive instruments was directed toward the development of expectancy tables for predicting parole violations (Burgess, 1928; Glueck and Glueck, 1929; Vold, 1935; Monachesi, 1945). Burgess (1928)

1 Recidivism is a technical term which is defined as a return to criminal activity after some intervening action, punitive or rehabilitative. 
constructed the first prediction tables for predicting parole success or failure. Using the data contained in the offender's official file, Burgess compared the percentage distributions for many variables and selected 21 which appeared to differentiate the violator and non-violator groups.

The Burgess prediction method assumed each variable to be of equal importance. Burgess's work was subsequently criticized (Hakeem, 1948; Glueck, 1956) for equal weighting of variables and for the inclusion of too many variables which did not increase the predictive strength of the instrument. However, it did persist as the predominant technique in the early attempts at predicting recidivism. Working contemporaneously with Burgess as pioneers in the development of prediction instruments were Eleanor and Sheldon Glueck (1929; 193ø). The Glueck's early technique differed from that of Burgess in that it attempted to identify only 5 or 6 significant factors for any given predictive instrument. This was accomplished by utilizing the coefficient of mean square contingency and selecting those factors which showed the highest contingency values in relation to post-parole criminality. In their later work, the Glueck's simplified their statistical methods (1934, 1937). This may have been the result of Vold's work (1935) which raised serious concerns about the adequacy of the contingency method for selecting predictive variables. 
Vold (1935) selected the Burgess method for his studies which focused on predicting the appropriateness of different treatment programs for various types of offenders. Vold's results showed that there were variables in the pre-prison life of an offender which could be utilized to predict an inmate's probable response to incarceration and, therefore, his treatment needs.

Vold's studies (1935) and those of Monachesi (1945) became the forerunners of a series of research efforts which focused on the problems and challenges associated with the development of prediction instruments. In general, this research argued that the application of the early prediction tables did not result in any greater accuracy than prediction from overall violation rates (Monachesi, 1945; Hakeem, 1948; Ohlin and Duncan, 1949). More specifically, Arnold (1965) found that the use of prediction tables only improved the chances of predicting parolees' success or failure an average of 12 percent beyond selection by pure chance.

Argow (1935) took a somewhat different approach and developed a criminal-liability index for predicting the probability of rehabilitation. He showed how a rehabilitation quotient could be obtained, given certain known characteristics of the histories of first offenders and recidivists. Argow transformed the probability of rehabilitation for first offenders into a numerical value by statistically comparing the difference between many factors 
in the life histories of first offenders and recidivists. Argow gives several case illustrations, but does not subject his index to tests of validity.

The Massachusetts state corrections system developed base expectancy categories for each of its correctional institutions to aid parole agencies in decision making (Metzner and Weil, 1963; Carney, 1967). These expectancy categories are much like those utilized by insurance companies to project life expectancy. An inherent problem with these categories is that they predict percentages of failures for specific profile groups rather than an individual's probability of success or failure. The Massachusetts work probably made its most significant contribution in emphasizing that changes in policy and prison populations influence and have a direct relationship to the variables which make up base expectancy categories and, therefore, continual monitoring and validation is essential. Metzner and Weil (1963) point out that the predictive variables were derived from the parole success or failure of past prison populations and, as prison population profiles change, predictive variables can lose their relevance. However, cross validation studies for the Massachusetts expectancy categories do not appear in the literature. The early work on predicting recidivism produced very few studies which tested the accuracy of the expectancy tables which were being utilized. Further, it appears that 
studies which made claims of validation were in actuality studies of reliability (Monachesi, 1950).

True validation and cross validation studies in the literature appear to be limited to those undertaken by the Gluecks. The Gluecks, who spent most of their lives carrying out validation studies of their recidivism prediction instruments, were successful in validating some of their instruments on populations where the composition and background factors differed remarkedly from the groups on which the tables were constructed (Glueck, 1956).

The most noted of such validations was one predicting military offenses, on the basis of juvenile misconduct, using an instrument which was developed for civilian purposes. Predictions in this case were accurate in $85 \%$ of the cases. Although the bulk of literature dealing with prediction of recidivism has utilized variables relating to personal characteristics, socio-economic factors and pre-parole criminal history, there are a few studies which approach the problem using something other than pre-institutional data. These include works by Laune (1935), Arnold (1965), and Frum (1958) .

One of the more innovative attempts at developing predictors for parolability was undertaken by Laune, who believed that an inmate's adjustment to life upon leaving prison was determined, in great part, by his attitudes. Laune's objective, therefore, was to find a means to assess 
attitudes and discover those attitudes which were predictive of parole success or failure. Laune hypothesized that a valuable source of information regarding parolability existed in the opinions or "hunches" of fellow inmates, since in a prison setting it is "quite generally believed that an inmate can size up his fellow inmates and estimate with some degree of accuracy his future conduct (Laune, 1935)."

Laune tested the reliability of inmates' hunches in terms of inter-rater reliability and found a correlation = +.62. Using a technique which simulates the present day Nominal Group Technique, Laune had inmates self-generate the factors which were at the basis of their hunches. Forty two factors were arrived at, and included such items as: selfishness; wanderlust; excessive interest in clothes; stupidity; timidity; sex craving; lack of love for relations; etc. Laune utilized these factors to construct a series of questionnaires which were administered to several group of inmates. Self disclosure on the questionnaires correlated +.68 with the inmates' hunches obtained earlier. When questionnaire scores were correlated with scores obtained by the Burgess method, an $r$ of .62 was achieved.

Arnold (1965) focused on the social relations of the parolee. He concluded that the processes of association and identification suggested by general role theory and differential association theory are crucial in bringing about criminal behavior in that the parolee will commit new crimes 
in an attempt to integrate with his groups and maintain his acceptability in them. Arnold argued that the social adjustments made during the first few months of parole could serve as a predictor of success or failure. The problem of predicting recidivism has also been investigated from a developmental point of view. In every study which has investigated recidivism, age at first arrest has been found to be a highly significant factor (Carney, 1967; Metzner and Weil, 1963, Mandel et al, 1965). These studies conclude that juvenile delinquency is often a forerunner of adult crime. Frum (1958) used a grid-charting method for compiling data on 319 recidivists. It depicts each individual's movement through time and "socio-judicial space," with 28 offenses on the vertical axis and an age scale on the horizontal axis. He found that about one-half of the recidivist population began their criminal careers prior to the age of 18. Also, his study confirmed that juveniles who commit minor delinquencies have a strong tendency to progress up the ladder to crimes of a more serious nature. (In Frum's research $92 \%$ of early juvenile offenders were at the level of adult property felonies.) Most importantly, Frum also observed that the offender profiles which he charted showed striking similarities, particularly in the area of property offenses. There was a strong relationship between juvenile stealing and subsequent adult property crimes. Further, many subjects in Frum's 
study persisted in adult life at the level of property felonies which were representative of their most serious juvenile offenses.

Finally, in the attempt to identify causal factors, several researchers have adopted a clinical approach which offers a predictive hypothesis. The hypothesis is based on the ideas that the recidivist population is characterized not only by low levels of achievement and inability to delay gratification, but also by growing up under substandard living conditions. Hypothesized results include a lack of development of the super-ego, low frustration tolerance and feelings of distrust for authority figures. Van West (1964) states that with regard to these personality factors and cultural background the recidivist population tends to be homogenuous .

As may be noted from the review of the diverse approaches to preciting recidivism, initially there was no general agreement over which factors were significant nor how many factors should comprise a prognostic instrument. However, out of this body of early research, a set of variables was identified which has repeatedly proven to have significance for predicting recidivism (Glueck, 193ø; Argow, 1935; Monachesi, 1950; England, 1955; Frum, 1958; Mandel, 1965; Carney, 1967). This set of variables included (a) age, (b) previous criminal activity, particularly involvement as a juvenile, (c) low level urban socioeconomic background, 
lack of job skills, and some element of personality disorder (usually rather ill-defined). A history of property crimes (type of offense) was also often included in the high risk profile.

The most recent research on predicting recidivism is distinguished primarily for the utilization of more sophisticated statistical tools (Wainer and Morgan, 1982; Brown 1978; Van Alstyne and Gottfredson, 1978; McEachern and Newman, 1969). These studies have focused on multivariate techniques and the interrelationships of the predictor variables. The only recent addition to the set of variables earlier identified as related to recidivism is drug use.

In addition to questions of parolability, prison and jail overcrowding have also increased interest in the use of sentencing alternatives, most of which utilize minimum security environment affording easy escape and reentry into society. Consequently, there are a few recent studies which examine the types of people who succeed or fail in alternative programs.

The few studies which have approached evaluation of sentencing alternatives in a scientific manner have yielded conflicting results. Lamb and Goertyel (1975) tracked men for three years after their release from a therapeutic residential facility which focused on vocational rehabilitation and job placement for serious offenders. In comparison to offenders released from prison, those given 
alternate sentences showed no difference in recidivism. The authors considered the alternative sentencing desirable for two reasons. First, those undergoing it showed no increase in recidivism when compared to prison releases. Second, this type of sentencing alternative, in contrast to prison, allows the inmates to continue working in the community thereby making it possible to meet financial obligations to family, victims (restitution) and other creditors.

An Australian study (Reiman, 1978) allowed offenders to convert a prison sentence to a specified number of hours to be spent in community work projects. This program, which included professional counseling to encourage social and community responsibility, reported only a $10 \%$ recidivism rate over a 3-4 year period.

In a controlled study, Jeffery and Woolpert (1974) compared the recidivism rates for a group assigned to work furlough and a group who served their time in a conventional prison environment. Jeffery and Woolpert's results indicated a surprising relationship between the number of prior convictions and the relative success of the work furlough and conventional prison sentences. There was no difference in recidivism between the work furlough and prison groups when only first and second offenders were compared. However, the work furlough program was significantly more successful for those participants who had two or more prior convictions before entering the program. Four years after release, 36\% 
of the high risk offenders who had participated in the work furlough program had no arrests. The high risk offenders in the control group, who had been imprisoned, had only 58 with no arrests following release.

Not only did the high risk offenders participating in the work furlough program have a lower recidivism rate than high risk offenders sent to prison, they also had a lower recidivism rate than low risk offenders participating in the work furlough program. Consequently, the alternate sentencing was not only relatively more successful with the high risk population, it was more effective with them in absolute terms as well.

On the basis of these results, Jeffery and Woolpert concluded that the work furlough program was most beneficial to those individuals who have the highest risk of failure upon release. High risk individuals were characterized as (a) unskilled, (b) unmarried, (c) under 35 years of age, (d) having 3 or more prior convictions.

The results of Jeffery and Woolpert's study suggest that precisely the wrong individuals are usually placed in work program alternatives. Typically the first or second offender is considered a prime candidate for a work program while the individual with a history of many prior convictions is sent to prison.

The remainder of the recent research on sentencing alternatives has focused on cost savings rather than 
prediction or measures of rehabilitative success or failure. In fact, Andrews and Kanner (1976) found in their review of creative sentencing that those programs which kept any statistics at all measured success in terms of completion of the program, or assigned work, rather than reform of the individual.

However, on the issue of cost savings and cost avoidance, there is sufficient documentation to support conclusions that alternatives to jail and prison are cheaper (Jeffery and Woolpert, 1974; Hudson et al, 1975; Galvin et al, 1977). This is especially true when their costs are compared to institutional costs averaging $\$ 15, \emptyset \emptyset \emptyset$ per year per person and new prison construction costs of approximately $\$ 5 \emptyset, \emptyset \emptyset \emptyset$ per bed (Umbreit, 198ø). 
CHAPTER III

DESCRIPTION OF THE PROBLEM

Americans lock up more people in prisons than any other nation in the free world (Galvin et al, 1977; Umbreit, 198ø). This occurs in spite of the fact that it is the opinion of many contemporary criminologists that the conventional prison environment, and the labeling process taking place in it, may be crucial factors in the development or learning of a criminality (Carney, 1967). Consequently, the argument for sentencing alternatives is founded on both economical and rehabilitative considerations. In addition there is an underlying assumption that in the population of criminal offenders there is a group that can be identified as "low risk" for whom alternate sentencing is most appropriate. Contrary to common belief, violent crime represents only 98 of all serious crime reported through Unified crime Reports. The remaining 918 are property related. Further, for all the individuals who are incarcerated, $98 \%$ will serve less than one year (Umbreit, 198ø).

The dilemma of determining which offenders are "safe" for release into the community is a problem which judges, corrections officials, and criminologists have been grappling 
with for well over a hundred years. Society's concern is not so much with what an offender has done in the past with what crimes that person may commit in the future.

Alternatives to jail or prison are generally minimum security environments which afford easy escape and reentry into society. Consequently, the problem of identifying what type of offender should be placed in alternative programs must deal with two predictive issues. The first of these is risk assessment which focuses on the probability of the individual committing further crimes which are commonly regarded as serious threats to society. These crimes include murder, rape, arson, assault, and armed robbery. The second predictive issue focuses on matching the program or resource, in this case the Forest Camp, with the individuals who will profit most from it in terms of rehabilitative potential. The purpose of this study is to determine to what extent a group of 88 subjects, who were sentenced to the Forest Camp in the early seventies, remained law abiding in the ten years which followed their release. In addition to analyzing recidivist patterns, the study attempts to identify which variables are associated with subsequent recidivist and non-recidivist behavior and relate those findings to previous studies in the Iiterature. 
CHAPTER IV

METHODS AND TECHNIQUES

The subjects in this study were 98 men who were sentenced to the Tillamook Forest Camp from the Multnomah County Circuit Court in the early 1970's.

In terms of the research literature, the subjects in this study who were sent to the Forest Camp would not be described as "low risk". In fact, quite to the contrary, the subjects generally fit a profile which previous studies have identified as having a high probability of recidivism. For example:

a) $38 \%$ were 15 or under at the time of their first arrest ;

b) $54 \%$ had 2 or more previous convictions;

c) $46 \%$ had 1 previous conviction;

d) $64 \%$ had involvement with drugs;

e) $7 ø \%$ were unskilled;

f) $65 \%$ were unemployed;

g) $89 \%$ were single or divorced;

h) $62 \%$ were between 16 and 23 years of age.

Although most of the subjects had previous records of law breaking, particularly as juveniles, none of the subjects 
had been incarcerated in a conventional prison environment prior to being sentenced to the Forest Camp.

A total of seven Circuit Court Judges utilized the Forest Camp as a sentencing alternative during the experimental period. This period extended from october, 1971, to February, 1973. The actual length of sentence, which was at the discretion of the sentencing judge, ranged from 15 days to 336 days.

Eliminated from the total group of 117 offenders who were sentenced to the Forest Camp, were 18 men who spent less than 2 weeks at the camp. These early terminations were due to:

1) Medical reasons

2) Request of inmate for transfer to conventional correctional facility

3) Disciplinary action

4) Escape

For each of the 98 subjects remaining in the study group, the level of recidivist activity, if any, which occurred during the $1 \emptyset$ to 12 year period following release from the Forest Camp was researched and recorded. This was accomplished by running a name search for each subject through the state of oregon's automated criminal history information system (LEDS) which interfaces with the national system and records all convictions. Another 10 subjects were subsequently eliminated from the study due to the inability 
to positively identify them in the LEDS criminal history files.

Using the conviction data carried in the LEDS system, the 88 subjects were classified using the following recidivist criteria:

Successful: No subsequent convictions $(n=45)$ Marginal Success: One conviction for which a probation term was imposed and not subsequently revoked $(\mathrm{n}=6)$

Marginal Failure: One conviction for which a jail term of less than 10 days was imposed $(n=2)$

Failure: One or more convictions for which a jail term of greater than 10 days was imposed $(n=35)$

These criteria are consistent with those established in other research in the literature (England, 1955; Moberg, 1972; Mandel et al, 1965; Brown, 1978). All of these studies agree that conviction and subsequent confinement are the most definitive criteria of recidivism.

Because of the small number of individuals in the marginal success and marginal failure categories, these categories were collapsed into the successful and failure groups respectively for purposes of statistical analysis. 
Data which were collected to determine recidivist patterns were:

1) Forest Camp probation revocation

2) Number of arrests since Forest Camp

3) Number of convictions since Forest Camp

4) Number of probations since Forest Camp

5) Number of probation revocations since Forest Camp

6) Number of jail terms greater than 6 months

7) Number of jail terms 6 months or less

8) Number of months elapsed since last conviction

9) Most serious conviction since Forest Camp 7=A Felony

6=B Felony

$5=\mathrm{C}$ Felony

$4=$ Parole/Probation Violation

$3=\mathrm{A}$ Misdemeanor

$2=B-C$ Misdemeanor

l=Technical Violation

Traffic violations were not included unless they were at the felony level.

After identifying the recidivist group, data describing their recidivist patterns were tabulated. A t-test was utilized to determine if there was a significant difference between the recidivist and non-recidivist groups in terms of length of sentence. Length of sentence was defined as number of days actually spent at the Forest Camp. 
The second part of the analysis examined the relationships between recidivist patterns and personal characteristics. Discriminate analysis was used to discover any significant differences between the recidivist patterns and personal characteristics and targeted to discover any significant differences between the recidivist and nonrecidivist groups.

For this analysis a subset of 47 subjects was utilized. The subset was determined by the availability of intact files with sufficient personal data recorded on the variables under analysis. These variables were:

1. Race

2. Age

3. Occupation Level

4. Employment Time of Forest Camp

5. Drug Use

6. Alcohol Dependent

7. Personality Disorder

8. Marital Status

9. Living Arrangements

10. Parents Economic status

11. Parents Marital Status

12. Age at First Arrest

13. Number of Arrests Before Forest Camp

14. Number of Convictions Before Forest Camp

15. Work Record at Camp 
16. Level of Forest Camp Offense

17. Type of Forest Camp offense

A breakdown of the categories within each variable is provided in Appendix A.

Data on personal variables came from two sources. These were:

1) Presentence Reports

2) Diagnostic Center Evaluations

Presentence reports were conducted by the county Probation Department. Diagnostic Center evaluations were performed by a clinical psychologist. The evaluation undertaken by the Diagnostic Center was a more in-depth assessment than the presentence report and usually resulted in the clinical psychologist making a specific recommendation as to the appropriateness of placing the offender in the Forest Camp. Written reports from both the probation Department and Diagnostic Center were submitted and placed in the offender's file prior to the sentencing decision.

The variables relating to personal characteristics were tested for their ability to discriminate between the two groups by applying the Chi square Test for independent samples for nominal data and the t-test for interval data.

Then the stepwise procedure of discriminate analysis was utilized to identify those variables which, when combined, had the strongest ability to discriminate between groups. 
The discriminant variables which were identified were tested for collinearity and their ability to correctly predict the actual group classification. In addition, the discriminant scores were plotted in relationship to the group centroids.

The Statistical Package for the Social Sciences (SPSS) was utilized to perform all statistical analysis.

Results of the analysis outlined in this chapter can be found in Chapter VI. 
CHAPTER V

RESULTS

The recidivism rate for the Forest Camp subjects was $42 \%$, with 37 of the men committing at least one crime, after release from the Forest Camp, for which they served a jail or prison term of six months or longer. However, it was found that 18 of the recidivist group have not had a conviction within the last 5 years. It is further interesting to note that $26(70 \%)$ of the recidivist group successfully completed the probationary period which followed their release from the Forest Camp. Most of the recidivist activity appears to have occurred in the time period immediately following termination of probation. Figure 2 shows the relationship between time elapsed and conviction for the first new offense for the recidivist group. This finding is consistent with the literature, in that most recidivism occurs during the first year to 18 months following release (England, 1955; Mandel, et al, 1965; Carney, 1967).

Following their release from the Forest Camp, the recidivist subjects had an average of 2.8 convictions per person. Of the total 111 convictions, a probation sentence was imposed in $38 \%$ of the cases. One-half of these probations were subsequently revoked with the concurrent 


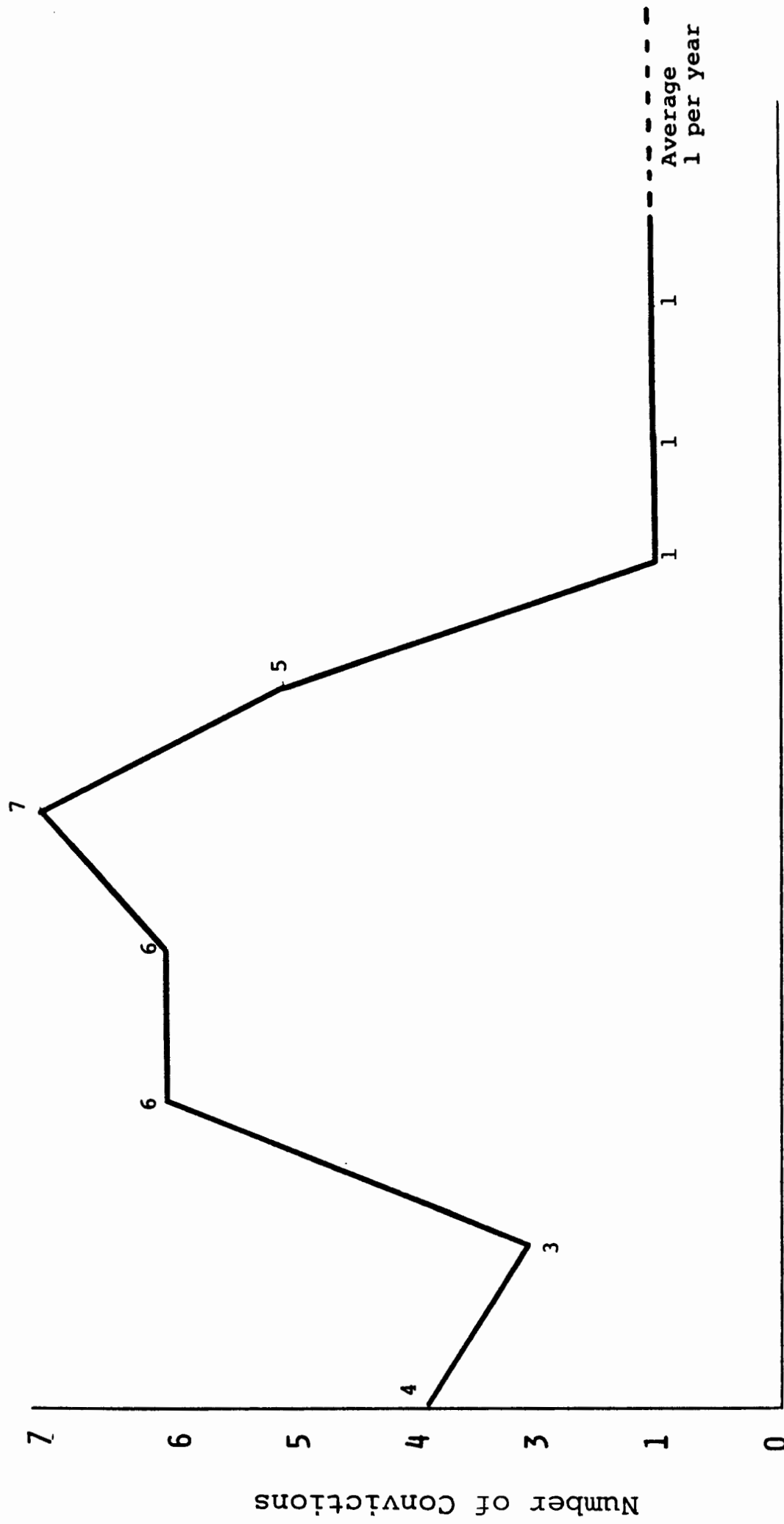

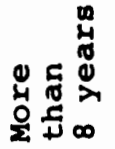

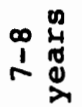

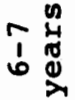

$Z$
0
$1-1$
0
$1-1$
$z$
0
0

嵒

us

3

㟧

त E

0

少

남

हु

U

I

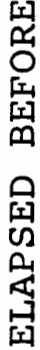

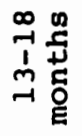

$\sum_{\text {E }}^{\text {岳 }}$

象点

م

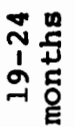


suspended jail or prison sentence becoming effective. Tables I and II present data on recidivist activity and the sentences imposed.

Generally speaking, the recidivist group returned to committing the same types of crimes for which they were initially sentenced to the Forest Camp. These were primarily C Felonies which were drug related or crimes against property. However, 10 of the recidivist group progressed to crimes of a more serious level. These convictions included 4 Class A Felonies, 3 for First Degree Robbery and 1 for Rape and sodomy. The remaining six convictions were for second Degree Robbery which is a Class B Felony ${ }^{2}$. of the 88 subjects, 51 (58\%) were classified as nonrecidivists, having no new convictions for which a prison or jail term was imposed. However, 7 of the non-recidivist group had their probation revoked after release from the Forest Camp, and served part of their suspended sentence (for the conviction for which they were sentenced to the Forest Camp) in a jail or prison environment. Further, the nonrecidivists were not arrest free, but tended to have far fewer arrests following their release than did the recidivist group. Table III presents a comparison of the recidivist and

2 Crimes are classified A, B, or C Felonies by oregon Statues with A Felonies encompassing the most serious crimes against persons. 
TABLE I

PATTERNS OF RECIDIVIST GROUP $\mathrm{N}=37$

Successful Completion of Forest Camp Probation:
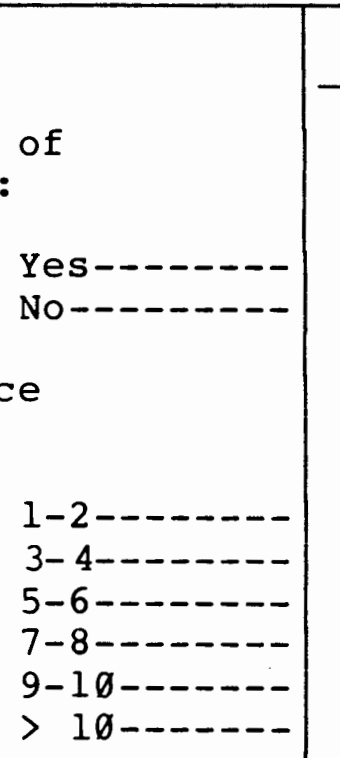

Number of Convictions Since Forest Camp:

Number of Arrests Since Forest Camp:

$1-2$

3- 4

$5-6$

7-8-..-.-

9-10--- - -

$>10 \ldots-\cdots$

$\sqrt{2}$

N

N

\section{T-}

Percent Cum.


TABLE 1 (Cont.)

Time Elapsed Since

Most Recent Conviction:

12 years or more-- 11 -

11 years--1$$
\text { 9 }
$$$$
9 \text { years }
$$

8 years--------

7 years------------------

6 years-

5 years----------------

4 years-

3 years-

2 years-

6 months

\begin{tabular}{|c|r|r}
$\mathrm{N}$ & Percent & $\begin{array}{c}\text { Cum. } \\
\text { Percent }\end{array}$ \\
& & \\
& & \\
1 & & 2.7 \\
3 & 2.7 & 10.8 \\
2 & 8.1 & 16.2 \\
5 & 5.4 & 29.7 \\
3 & 13.5 & 37.8 \\
1 & 8.1 & 40.5 \\
4 & 2.7 & 51.3 \\
5 & 10.8 & 64.8 \\
2 & 13.5 & 70.2 \\
2 & 5.4 & 75.6 \\
6 & 5.4 & 91.8 \\
2 & 16.2 & 97.2 \\
1 & 5.4 & 99.9 \\
& 2.7 & \\
\hline
\end{tabular}


TABLE I I

SENTENCES IMPOSED ON RECIDIVIST GROUP

Number of Probations since Forest Camp: 1

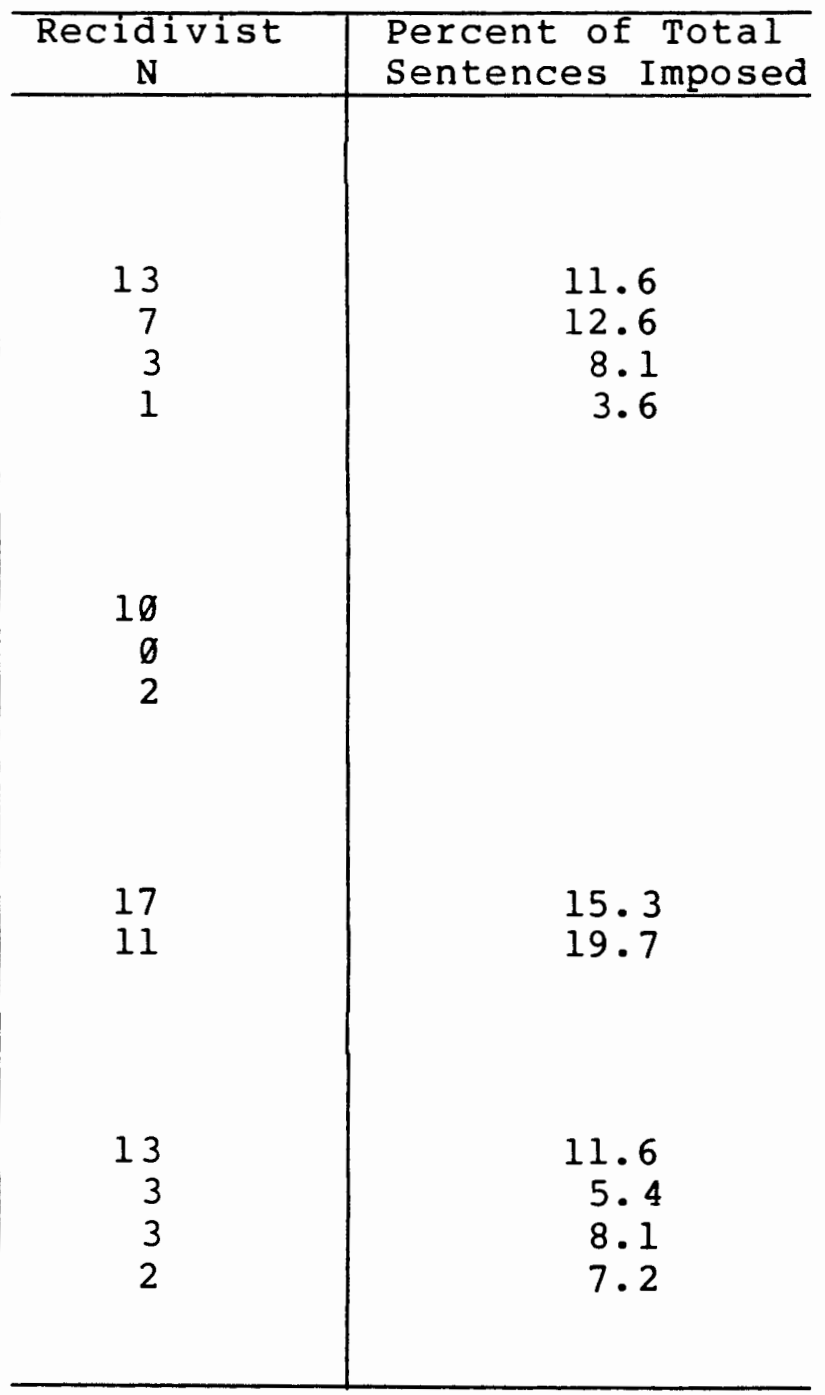

Number of Probation Revocations Since Forest Camp:

Number of Jail Terms > 6 months:
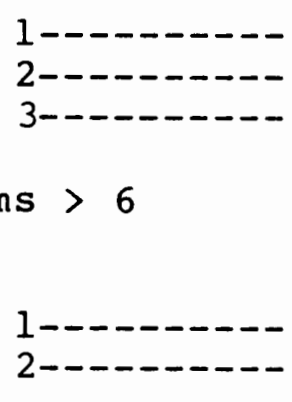

Number of Jail Terms $<6$ months: 1

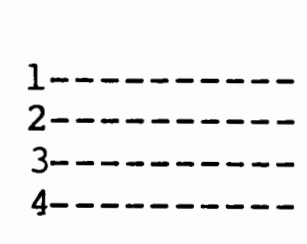

1 Seven subjects who received both probation and a jail term of $1 \emptyset-3 \emptyset$ days as a combined sentence are double counted. 
TABLE I I I

Comparison of Post Release Involvement in Criminal Justice System for Recidivist and Non-Recidivist Groups

Length of Forest Camp Sentence (days)

Successful Completion of Forest Camp Probation:

Number of Arrests Since Forest Camp:

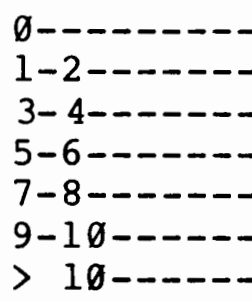

Number of Convictions Since Forest Camp:

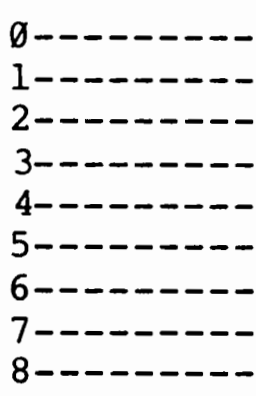

Most Serious Conviction:

A Misdemeanor Parole - Probation----Violation

C Felony

B Felony

A Felony

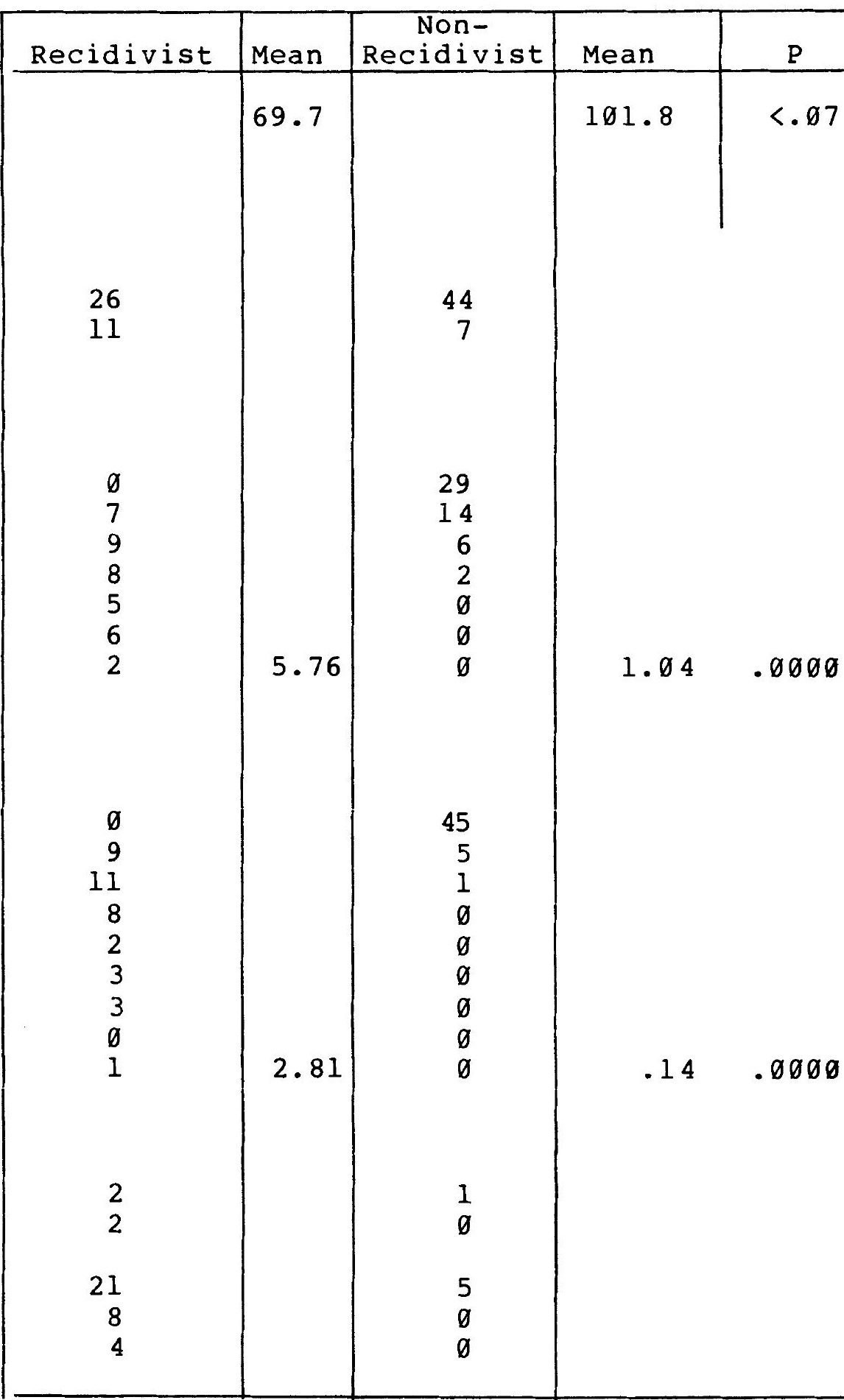


TABLE III (Cont.)

Number of Probations Since Forest Camp: 1

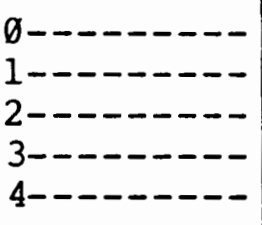

Number of Probation Revocations Since Forest Camp:

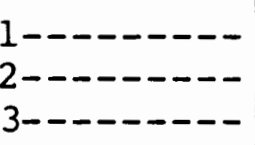

Number of Jail Terms > 6 months :

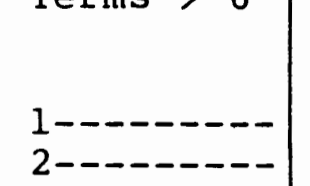

Number of Jail Terms $<6$ Months : 1

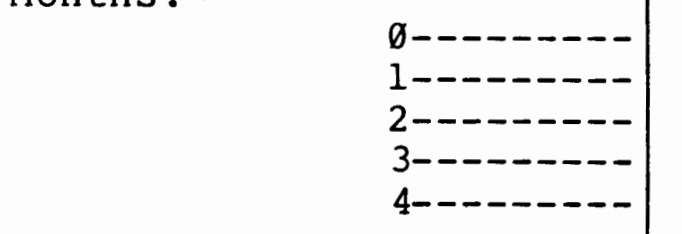

\begin{tabular}{|l|l|c|l|l} 
Recidivist & Mean & $\begin{array}{c}\text { Non- } \\
\text { Recidivist }\end{array}$ & Mean & $\mathrm{P}$ \\
\hline
\end{tabular}

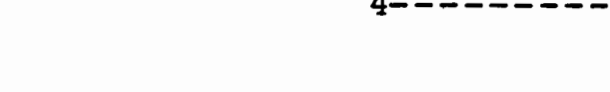

17

11

10
$\emptyset$
2

13

7

3

1

1.68

$\emptyset$

2

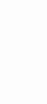

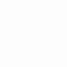

$$
\begin{array}{r}
.43 \\
1.05 \\
.7
\end{array}
$$

.02

.1

.$\varnothing \emptyset \emptyset$

1 Seven subjects who received both probation and a jail term of 10-30 days as a combined sentence are doubled counted. 
TABLE III (Cont.)

\begin{tabular}{|c|c|c|c|c|c|c|}
\hline \multirow[b]{2}{*}{$\begin{array}{l}\text { Time } \\
\text { Most }\end{array}$} & \multirow[b]{2}{*}{$\begin{array}{l}\text { Elapsed Since } \\
\text { Recent Conviction: }\end{array}$} & \multirow[t]{2}{*}{ Recidivist } & \multirow[t]{2}{*}{ Mean } & $\begin{array}{c}\text { Non- } \\
\text { Recidivist }\end{array}$ & Mean & Signif \\
\hline & & & & & & \\
\hline & 12 or more- & 1 & & 28 & & \\
\hline & 11 years- & 3 & & 2 & & \\
\hline & 10 years--1-- & 2 & & $\emptyset$ & & \\
\hline & 9 years-- & 5 & & 1 & & \\
\hline & 8 years- & 3 & & 1 & & \\
\hline & 7 years- & 1 & & $\emptyset$ & & \\
\hline & 6 years--- & 4 & & $\emptyset$ & & \\
\hline & 5 years-n- & 5 & & $\theta$ & & \\
\hline & 4 years- & 2 & & $\emptyset$ & & \\
\hline & 3 years-- & 2 & & 1 & & \\
\hline & 2 years-n- & 6 & & 1 & & \\
\hline & 6 months & 2 & & 1 & & \\
\hline & less than 6 months & 1 & 65.8 & $\emptyset$ & 123.6 &.$\emptyset \emptyset 4$ \\
\hline
\end{tabular}


non-recidivist groups in terms of their involvement with the criminal justice system following release from the Forest Camp.

The recidivist and non-recidivist groups also varied significantly in the length of time spent at the Forest Camp, with the non-recidivist group averaging sentences which were one-third longer than the recidivist group. Length of sentence was significant at the .ø7 level of significance. Table III also includes these data.

The second part of the analysis compared the personal characteristics and criminal history for a subset of 47 subjects for whom complete files could be located. Of the 47 subjects, 20 met the criteria of recidivist and 27 were nonrecidivist. Tables IV and $V$ present the significance of each of these variables, which previous studies have traditionally examined, for the recidivist and non-recidivist groups. Using appropriate univariate analysis, Chi Square for nominal data and t-test for interval data, only two variables, marital status and parents' economic status, proved significant at the .05 level of significance. Consequently, in utilizing univariate techniques, one would conclude that the recidivist and non-recidivist groups appear quite similar in terms of their backgrounds and personal characteristics. Table IV provides data for those variables significant at the 
5\% level or less. Table $V$ includes those variables not significant at that level.

The variables were further analyzed for their ability to discriminate between the recidivist and non-recidivist groups by applying the multivariate technique of stepwise discriminate analysis. Discriminate analysis, by weighting and linearly combining the variables which make the two groups as statistically distinct as possible, takes account of the interrelationships among the variables whereas univariate techniques do not.

Seventeen variables which previous research identified as predictive of recidivist tendencies were included in the stepwise discriminant analysis. The discriminant model which emerged contained five variables which discriminated between the recidivist and non-recidivist groups. These were: 1) Age at time sent to the Forest Camp; 2) Number of prior arrests; 3) Number of prior convictions; 4) Personality disorder; and 5) Drug use. A sixth variable, parents economic status, entered the discriminant model on the first iteration but was later eliminated because it did not significantly enhance the overall discriminant ability of multivariate model. Table VI presents the order in which the 6 discriminatory variables entered stepwise discriminant analysis model and their relative importance. Relative importance is determined by the standardized coefficient which is also provided. 


\section{TABLE IV}

Variables Significant at the 5 Percent Level or Less

\begin{tabular}{l|c|c|c}
\hline & $\begin{array}{c}\text { Single } \\
\mathrm{N}=29\end{array}$ & $\begin{array}{c}\text { Married } \\
\mathrm{N}=5\end{array}$ & $\begin{array}{c}\text { Divorced } \\
\mathrm{N}=12\end{array}$ \\
\hline $\begin{array}{l}\text { Recidivist ........ } \\
\text { Non-Recidivist........ }\end{array}$ & $12\left(\begin{array}{l}12.4) \\
17(58.6)\end{array}\right.$ & $\begin{array}{l}\emptyset \\
5(1 \emptyset \emptyset . \emptyset)\end{array}$ & $\begin{array}{l}8(66.7) \\
4(33.3)\end{array}$ \\
\hline
\end{tabular}

$$
x^{2}=6.52, d f=2, p<.03
$$

\#2

Parents Economic Status

\begin{tabular}{l|c|c|c|c}
\hline & $\begin{array}{c}\text { Comfortable } \\
\mathrm{N}=18\end{array}$ & $\begin{array}{c}\text { Fair } \\
\mathrm{N}=1 \emptyset\end{array}$ & $\begin{array}{c}\text { Marginal } \\
\mathrm{N}=9\end{array}$ & $\begin{array}{c}\text { Welfare } \\
\mathrm{N}=6\end{array}$ \\
\hline $\begin{array}{l}\text { Recidivist } \\
\text { Non-Recidivist }\end{array}$ & $\begin{array}{c}8(44.4) \\
1 \emptyset(55.6)\end{array}$ & $\begin{array}{c}1(1 \emptyset . \emptyset) \\
9(9 \emptyset . \emptyset)\end{array}$ & $\begin{array}{l}6(66.7) \\
3(33.3)\end{array}$ & $\begin{array}{c}4(66.7) \\
2(33.3)\end{array}$ \\
\hline
\end{tabular}

$$
x^{2}=7.81, d f=3, p<.95
$$


TABLE V

Variables Not Significant at the .05 Level

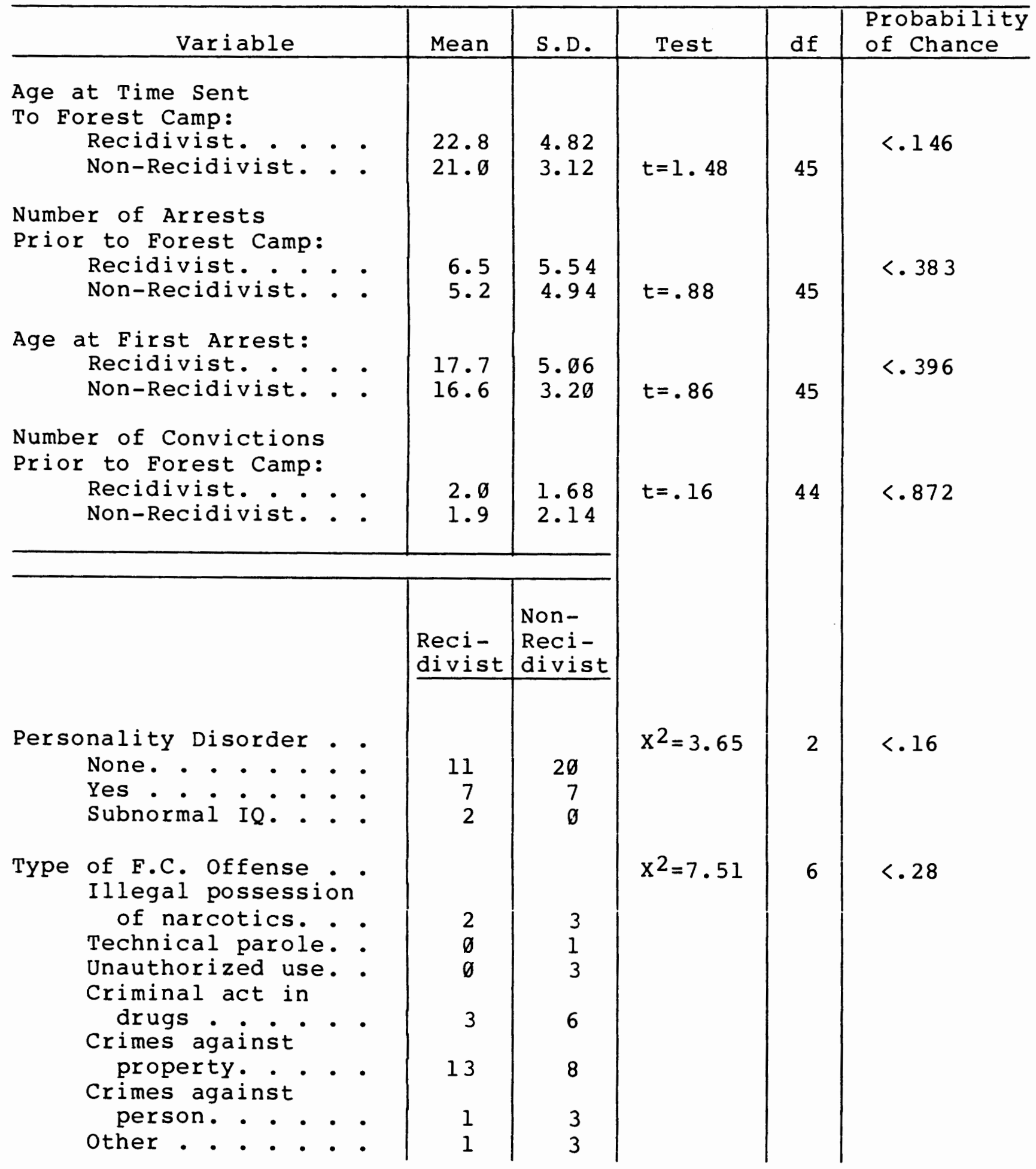




\section{TABLE V (Cont.)}

Variables Not Significant at the .05 Level

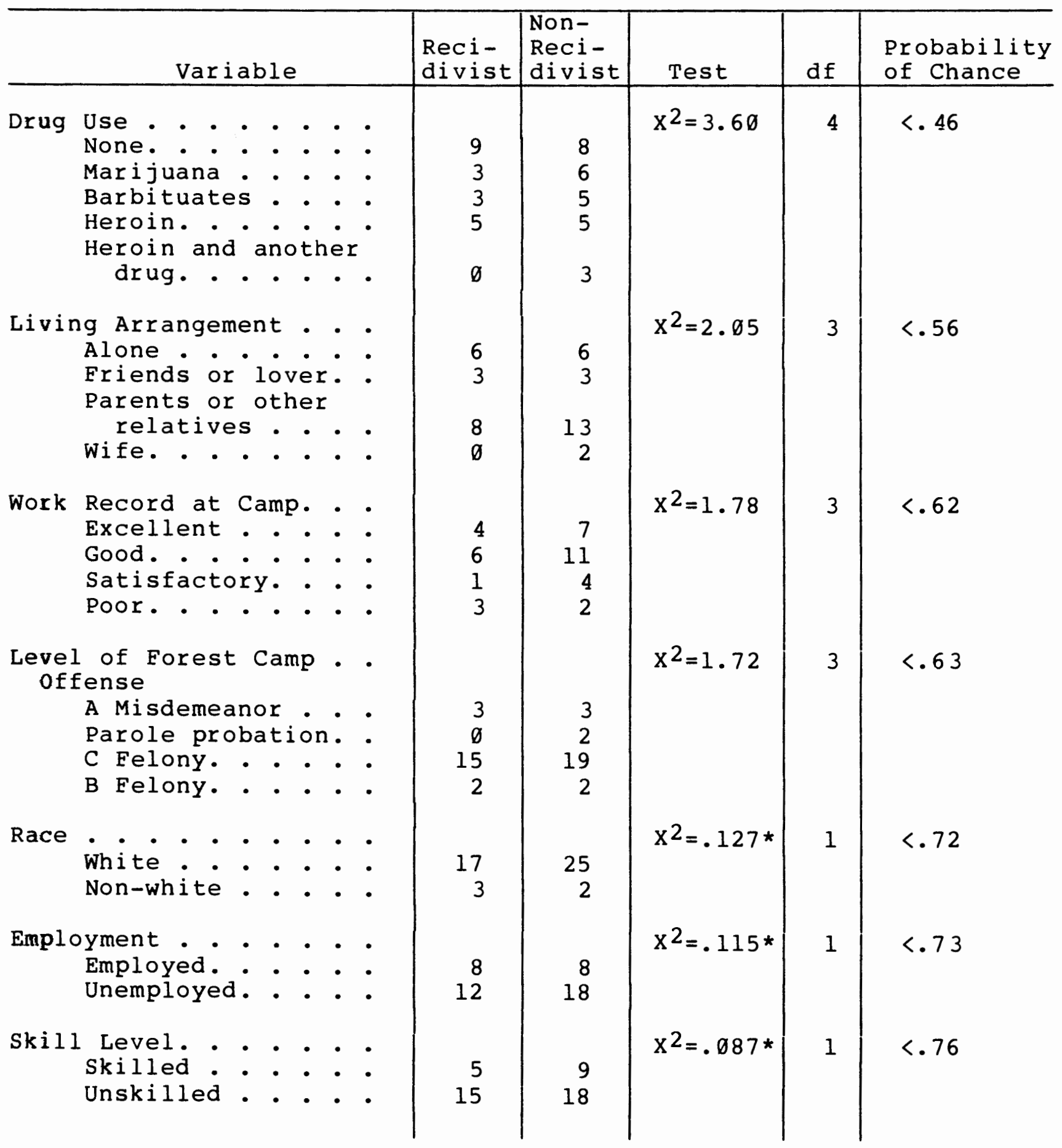


TABLE V (Cont.)

Variables Not Significant at the .05 Level

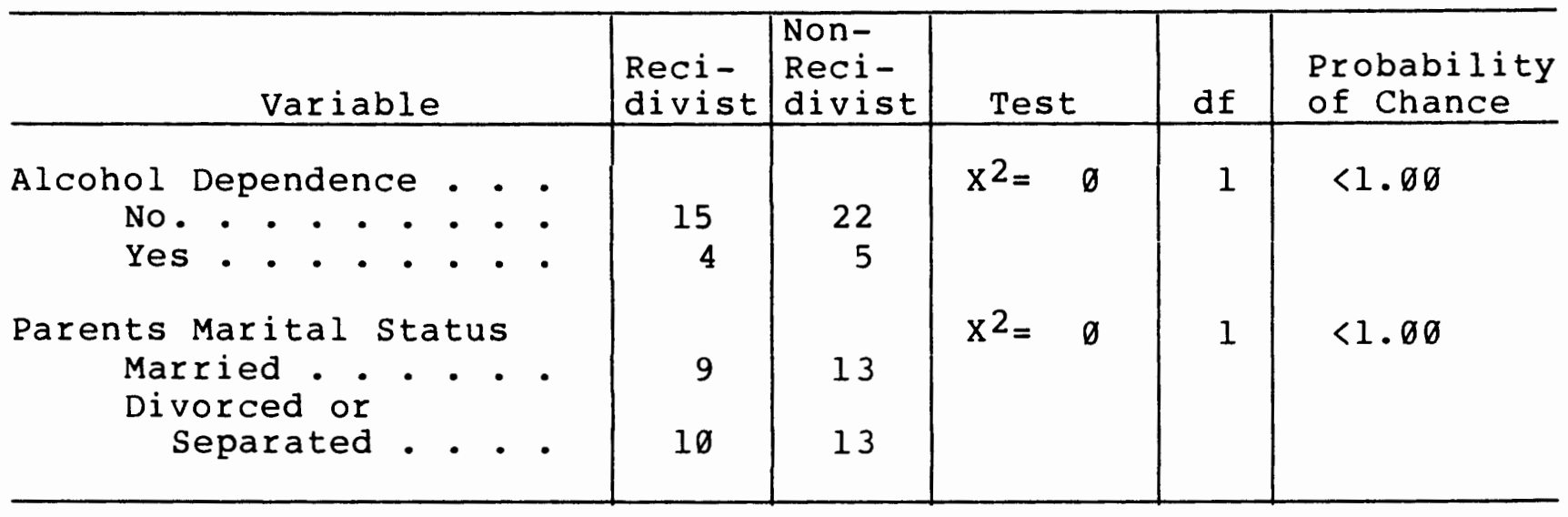

* Adjusted Chi Square 
TABLE VI

Discriminant Function Coefficients ${ }^{1}$

Order of Relative Standardized

Entry

Importance

Coefficients

Parents Economic Status

1

Age at Time sent to

Forest Camp

Personality Disorder

Convictions Prior to

Forest Camp

Drug Use

5

5

.509

Number of Arrests Prior to Forest Camp

6

4

$-.609$

$1 \mathrm{x}^{2}=9.92, \mathrm{df}=5, \mathrm{p}<.075$ 
Neither of the variables which were found to be significant using univariate methods were included in the final discriminant analysis model by virtue of their $\mathrm{F}$ values for that function. Although parents economic status was the variable with the greatest univariate discriminating power, this variable was eliminated in the final iteration of the computer analysis. This occurred because in the multivariate context parents economic status did not increase the $\mathrm{F}$ statistic for the discriminant function. In other words, all the discriminating ability of this single variable was contained in the five variables which remained in the model. The utilization of discriminant coefficients as determinents of the relative importance of discriminating variables relies on the underlying assumption that the variables are not highly collinear. Therefore, this assumption was tested by running simple correlations between each pair of discriminating variables. The results, which are presented in Table VII, reveal very little collinearity with the exception of that between arrests and convictions, which is to be expected since one must be arrested to be convicted.

Finally, in completing the analysis, the discriminant model was tested for its ability to correctly classify the recidivist and non-recidivist groups by comparing the predicted outcome to the actual outcome. The model correctly 


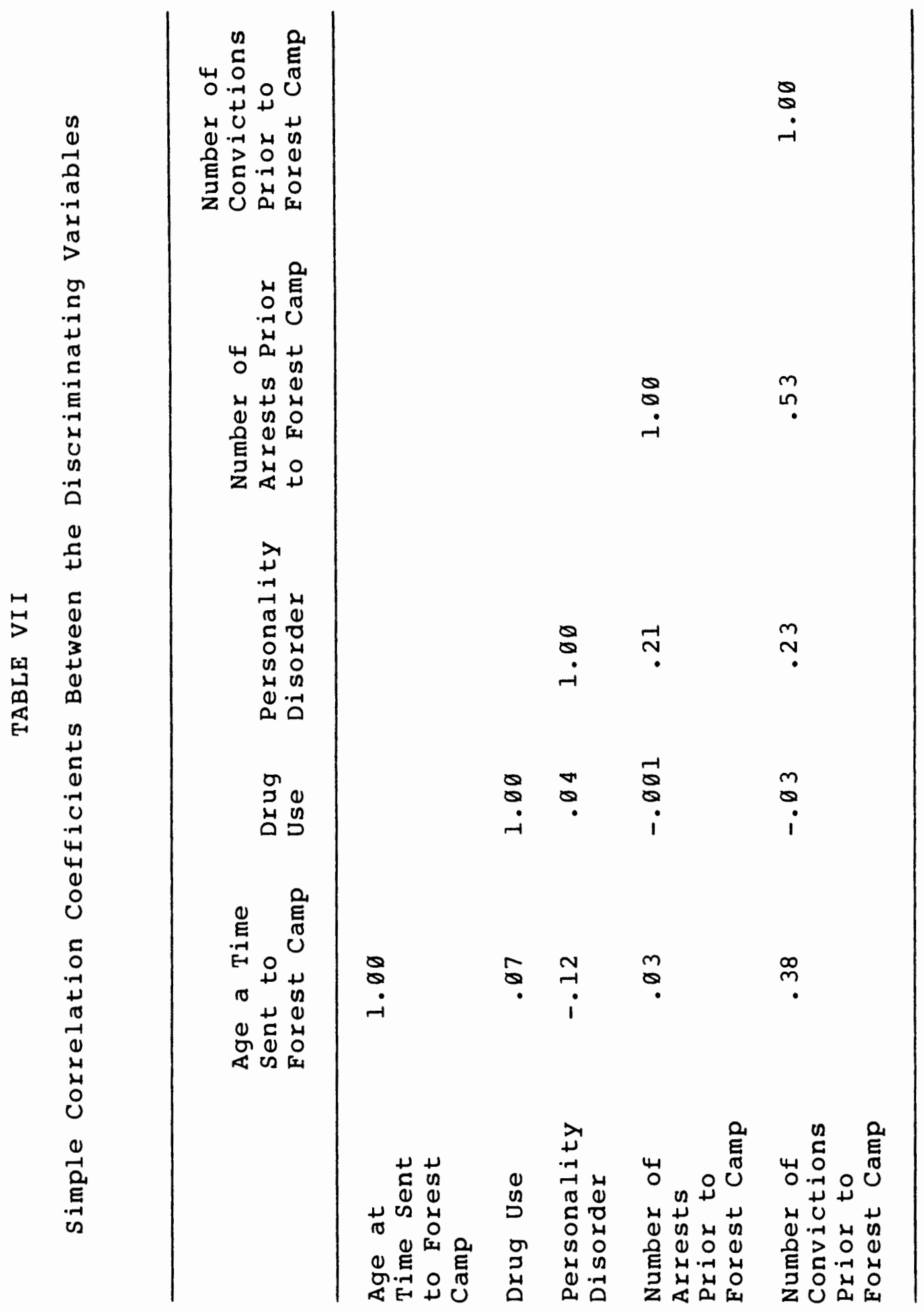


classified the subjects in 79.28 of the cases. The Type 1 and Type 2 errors are shown in Table VIII.

\author{
TABLE VIII
}

Classification Results Using Discriminant Model

\begin{tabular}{l|c|c|c}
\hline Actual Group & $\begin{array}{c}\text { No. of } \\
\text { Cases }\end{array}$ & $\begin{array}{c}\text { Predicted } \\
\text { Group } \\
1\end{array}$ & $\begin{array}{c}\text { Membership } \\
3\end{array}$ \\
\hline Recidivist (1) & 20 & 15 & 5 \\
Non Recidivist (3) & 27 & 75.0 & 15.9 \\
& & 33.3 & 66.7 \\
\hline
\end{tabular}

Percent of Grouped Cases Correctly Classified $=70.21$

In this case, both Type I and Type II errors have costs associated with them. If a Forest Camp inmate, who is predicted as a non-recidivist a priori, commits new crimes upon escape or release, there are costs to victims and costs to the jurisdiction for processing through the judicial and correctional system (Type I error). However, if an offender is predicated a recidivist a priori, and is sentenced to a prison term when he actually would have fallen in the success 
category, scarce and costly prison space is unnecessarily used.

It is further evident from Table VIII that recidivists (or failures) can be more accurately predicted than nonrecidivists (successes).

Table IX presents a plot of the discriminant scores in relation to the group centroids. Group centroids are the mean discriminant scores for each group. Errors in prediction can be easily identified from the plotted data. 
i

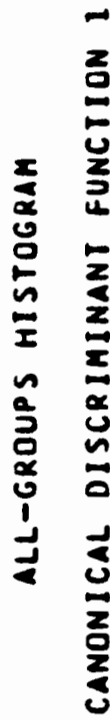

范

$\geq$

욜워

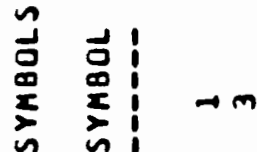

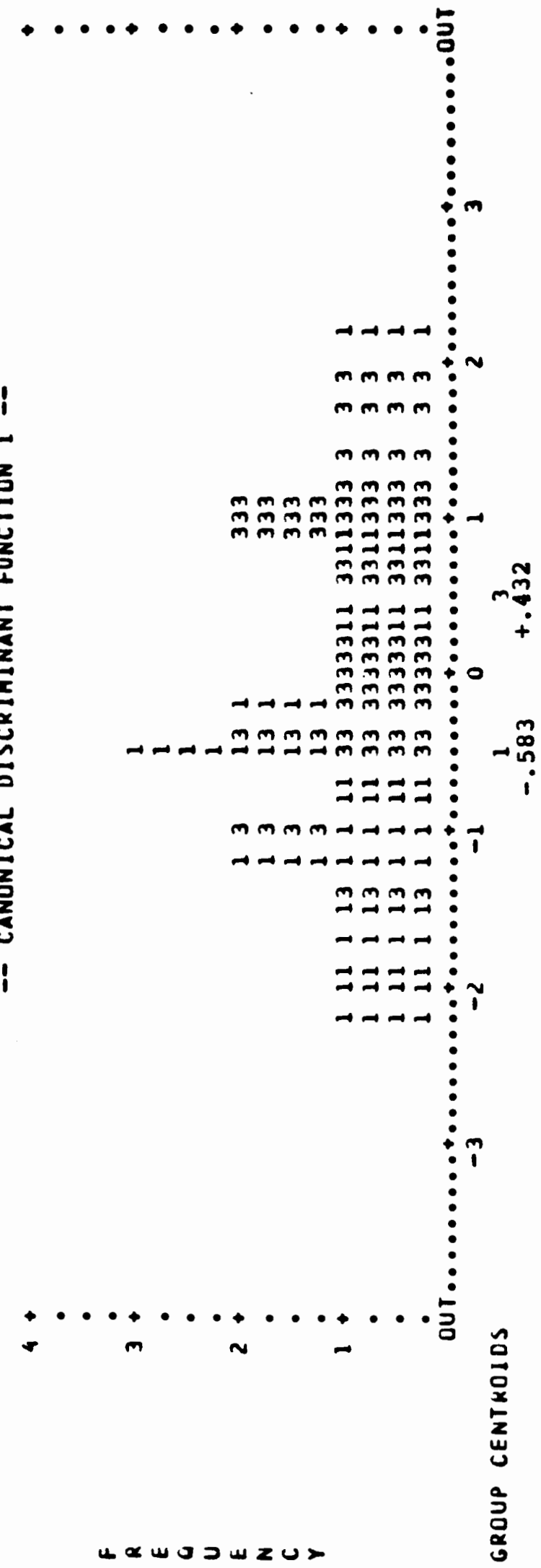




\section{CHAPTER 6}

\section{DISCUSSION}

The findings that the number of prior arrests and number of prior convictions were both included in the discriminant model are consistent with other studies in the literature (Gluecks, 1943; England, 1955; Metzner and Weil, 1963; Mandel et al, 1965; Carney, 1967). These studies have concluded that one's past involvement with the criminal justice system, as reflected in both arrests and convictions, is a strong determinant of whether future crimes will be committed. It is interesting to note that the non-recidivist group has $18 \%$ more convictions per arrest than the recidivist group prior to their Forest Camp commitment. The difference in ratios of convictions to arrests for the two groups does indicate that prior entry into the criminal justice system for the non-recidivist group has reached a greater degree of closure than for the recidivist group. This may have some significance given the theory that altering criminal behavior is in part dependent upon experiencing, in a timely manner, the full impact of the negative sanctions inherent in the criminal justice process. This explanation is based on deterrence theories (Wilson, 1976) which, in the case of non- 
violent criminal behavior, assume that the would-be offender makes a cost-benefit decision in terms of risk; that is, the risk of being caught and the risk of being prosecuted. obviously, if one is repeatedly arrested but not processed through the criminal justice system it is plausible that the perceived risk, or cost, of criminal behavior may decrease and the offender will persist in criminal behavior for which the benefit out weights the potential cost, based on past experiences.

In studies of recidivism, typically the recidivist population is characterized by low self esteem, immaturity and anomie (Van West, 1964; Jeffery and Woolpert, 1974). For Forest Camp subjects these traits were classified as personality disorders. As a discriminant factor, personality disorder was ranked third in importance with the nonrecidivist group having a smaller proportion of subjects diagnosed as having personality disorders. However, there are two other results in this study which generally differ from previous research findings.

Research in the area of recidivism has repeatedly found age at admission to be a significant predictor, with younger offenders being more prone to continued criminal activity following release (Gluecks, 1940; Frum, 1958; Metzner and Weil, 1963; Carney, 1967). The discriminant analysis in this study found age to be the most important factor for predicting recidivism for the Forest Camp subjects. However, 
contrary to most of the literature, the non-recidivists in this study were, on the average, 18 months younger than the recidivist group upon admission to the Forest Camp.

In addition to being younger, the non-recidivist group also had a higher proportion of drug users upon admission to the Forest Camp than did the recidivist group.

This could be explained by the simple fact that if one is committing crimes to support a drug habit and is placed in an environment where the drug habit is altered, they no longer have the need to commit crimes. This is in direct contrast to the career criminal whose unlawful behavior is motivated by a different set of needs and circumstances.

In summary, the findings of this study might be viewed as similar to those of Jeffery and Woolpert (1974) who found a higher degree of success in their work furlough program for individuals who were predicted to have the highest risk of failure upon release. Jeffery and Woolpert explained their results in terms of the high risk group having fewer sources of self-esteem and, therefore, being more susceptible to the positive labeling effect derived from meaningful work and the overall work furlough experience.

Similarly, successful completion of the Forest Camp experience, which is basically a rigorous, out-of-doors, spartan existence could have had a greater impact on the high risk group if they had fewer past opportunities for positive reinforcement and personal successes. Increased self-esteem 
is one plausible explanation for the higher risk group being more law abiding upon release.

Finally, the longer sentences which the non-recidivists tended to serve at the Forest Camp appear to have had some degree of effectiveness particularly if drug use was involved.

In summary, the profiles of the recidivist and nonrecidivist groups were quite similar in terms of background and personal characteristics. However, the factors of age at admission, number of prior arrests and convictions, personality disorder, and drug use interacted in such a way as to differentiate the recidivist and non-recidivist groups. There are limitations to this research, most of which are the consequence of not having control over the research environment; and, therefore, the absence of a rigorous experimental design. However, the researcher who strives to obtain the classic research model for study in the field of criminal justice will soon find that reality and the underpinnings of the system rarely allow for the optimum of random assignment, control groups, and controlled systematic data collection.

Given those caveats, there are some observations to be made from this research endeavor and its implications. The group of subjects had an overall profile which is generally accepted as high risk in terms of probability of recidivsm. In spite of this fact, slightly more than one- 
half of the group remained crime free over a follow up period of $1 \varnothing-12$ years.

We don't know, and can't assume, what the recidivism rate would have been had this group been sent to prison. However, we do know that the cost of prison housing is approximately 4 to 5 times that of the Forest Camp. In addition, jail and prison space is well recognized as a shrinking resource in the criminal justice system and the utilization of this space for Class C Felons has been both a local and national issue for approximatley the last 15 years. As jails and prisons become increasingly overcrowded, there will be a still greater need to expand sentencing alternatives.

Sociologists and Criminologists argue the need for sentencing alternatives on the basis that alternative programs have the strongest potential for reform and rehabilitation. Closely tied to this is the opportunity to incorporate meaningful work as an essential part of the rehabilitative process. However, the continued reliance on prisons and retarded expansion of sentencing alternatives in the United States is, in part, directly related to the absence of data which proves sentencing alternatives to be effective. This is not to suggest that we have evidence that prisons are effective, but rather that funding for innovative treatment methods is usually dependent on documenting a level of program success. 
Systematic evaluation of sentencing alternatives should target to measure the extent to which the sentence imposed achieves the objective of deterring further criminal activity. In other words, as social scientists, we are asking, "how effective was the treatment over time as measured by subsequent recidivist activity?" This can only be accomplished by tracking program participants over an extended period of time following their release. Longitudinal research is extremely rare in the field of corrections.

The early work in the area of sentencing alternatives focused on need for alternatives from the position that a justice system which presents only two treatment alternatives, prison or probation, lacked flexibility. In 1984 the problem is not to establish the need for sentencing alternatives, but to research and document which programs are effective and for whom. 
REFERENCES

American Bar Association Journal, 1976, 62, 1297

Andrews, Lori B. and Stephen B. Kanner 1976. "Tailoring the Sentence to Fit the Criminal." Update, 6, 18-24.

Argow, W. W. 1935. "A Criminal-Liability Index for Predicting the Possibility of Rehabilitation," Journal of Criminal Law and Criminology, 26, 561-577.

Arnold, W. R. 1965. "A Functional Explanation of Recidivism," Journal of Criminal Law and Criminology, $56,212-219$.

Barnes, H. E. and N. Teeters 1959. New Horizons in Criminology ( 3 rd ed.) Englewood Cliffs, N.J.: Prentice Hall; Cited by Stanley L. Brodsky 1972. Psychologists in the Criminal Justice System. Marysville, Ohio: American Association of Correctional Psychologists, p. 63.

Brown, L. D. 1978. "The Development of a Parolee Classification System Using Discriminant Analysis," Journal of Research in Crime and Delinquency, 15, 92-168.

Bruce, A. A., A. J. Harno, E. W. Burgess, and J. Landesco 1928. Parole and the Indeterminate Sentence Springfield, Illinois: Illinois state Board of Parole.

Carney, F. J. 1967. "predicting Recidivism in a Medium Security Correctional Institution," Journal of Criminal Law and Criminology, 58, 338-348.

England, R. W. 1955. "A Study of Post probation Recidivism Among Five Hundred Federal Offenders," Federal Probation, 19, 1ø-16.

Foote, Calib 1972. "The Sentencing Function," A Program for Prison Reform, 17-32.

Frum, H. S. 1958. "Adult Criminal Offense Trends Following Juvenile Delinquency," Journal of Criminal Law and Criminology, 29, 29-48. 
Galvin, John J., Walter H. Busher, William Greene, Gary Kemp, Nora Harlow and Kathleen Hoffman 1977. Instead of Jail: Pre and Past Trial Alternatives to Jail Incarceration. National Instititute of Law Enforcement and Criminal Justice, Washington, D.C.

Glueck, Sheldon and Eleanor T. 1929. "Predictability in the Administration of Criminal Justice," Harvard Law Review, $42,3 \emptyset \emptyset-329$.

Glueck, Sheldon and Eleanor T. 193ø. 500 Criminal Careers. New York: Alfred A. Knopf.

Glueck, Sheldon and Eleanor T. 1934. 50ø Delinquent Women. New York: Alfred A. Knopf.

Glueck, Sheldon and Eleanor T. 1937. Later Criminal Careers. New York: The Commonwealth Fund.

Glueck, Sheldon and Eleanor T. 1940. Juvenile Delinquents Grown Up. New York: The Commonwealth Fund.

Glueck, Sheldon and Eleanor T. 1943. Criminal Careers in Retrospect. New York: The Commonwealth Fund.

Glueck, Eleanor T. 1956. "Status of Glueck Prediction Studies," Journal of Criminal Law and Criminology, $47,18-27$.

Gottfredson, Don M. 1972. "Five Challenges," In Stanley L. Broodsky (Ed.), Psychologist in the Criminal Justice System. Marysville, Ohio: American Association of Correctional Psychologists.

Hakeem, Michael 1948. "The Validity of the Burgess Method of Parole Prediction," American Journal of Sociology, $53,376-386$.

Hudson, Joe, Burt Galaway, William Herschel, Jay Lindgren, and Jon Renton 1975. "Diversion Programming in Criminal Justice: The Case of Minnesota," Federal Probation, 39, 11-19.

Jaffe, A. and A. Reed 1969. "Jamming the Revolving Door," Federal probation, 33, 32-36.

Jeffery, Robert and Stephen Woolpert 1974. "Work Furlough as an Alternative to Incarceration: An Assessment of its Effects on Recidivism and Social Cost," The

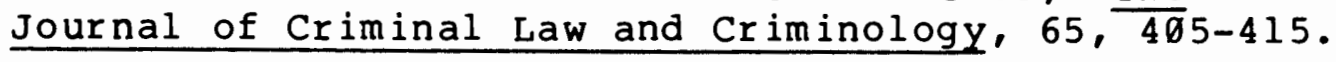


Lamb, Richard H. and Victor Goertyel 1975. "A Community Alternative to County Jail: The Hopes and Realities," Federal probation, 39, 33-39.

Laune, F. F. 1935. "A Technique for Developing Criteria of Parolability," Journal of Criminal Law and Criminology, 26, 41-45.

Mandel, N. G., Beverly Collins, M. R. Moran, A. J. Barron, F. J. Gelbmann, C. B. Gadbois and Philip Kaminstein 1965. "Recidivism Studied and Defined," Journal of Criminal Law and Criminology, 56, 59-66.

Marcus, B. 1955. "Intelligence, Criminality, and Expectation of Recidivism," British Journal of Delinquency, 6 , 147-151.

McEachern, Alexander and Robert J. Newman. "A System for Computer-Aided Probation Decision Making," Journal of Research in Crime and Delinquency, July 1969, 184-198.

Metcalf, H. M. 1935. "Recidivism and the Courts," Journal of Criminal Law and Criminology, 26, 367-376.

Metzner, R. and G. Weil 1963. "Predicting Recidivism: BaseRates for Massachusetts Correctional Institution Concord," Journal of Criminal Law and Criminology, $54,307-32 \overline{1}$.

Moberg, D. O. and R. Ericson 1972. "A New Recidivism Outcome Index," Federal probation, 36, 5ø-57.

Monachesi, Elio D. 1945. "A Comparison of Predicted with Actual Results of Probation," American Sociology Revue, 10, 26-31.

Monachesi, Elio D. 195ø. "American Studies in the prediction of Recidivism," Journal of Criminal Law and Criminology, $41, \frac{268-289 .}{}$

Mueller, Gerhard O.W. 1972. "Imprisonment and Its Alternatives," A Program for Prison Reform, 33-46.

Ohlin, L. E. and Otis D. Duncan 1949. "The Efficiency of Prediction in Criminology," American Journal of Sociology, 441-451.

Reiman, Thomas A. 1978. "Community Corrections in Australia: The Attendance Center Scheme," Federal Probation, 42, $5 \emptyset-54$. 
President's Commission on Law Enforcement and Administration of Justice, The Challenge of Crime in a Free Society, Washington, D.C.: United States Government Printing Office, 1967.

Roat, Lawrence S. 1973. "State Work Release Programs: An Analysis of Operational Policies," Federal Probation, $37,52-58$.

Sellin, T. and M. E. Wolfgang 1964. Measurement of Delinquency. The New York: John Wiley and Sons.

Shimberg, M. E. and J. Iraelite 1933. "A Study of Recidivists and First offenders of Average and Defective Intelligence," American Journal of orthopsychiatry, 3, 175-180.

Short, J. F. and F. L. Strodtbeck 1963. "The Response of Gang Leaders to Status Threats: An Observation on Group Process and Delinquent Behavior," American Journal of Sociology, 68, 571-579.

"Turn 'em Loose": Toward a Flexible Corrections System. Southern California Law Review, 1969, 42, 682-699.

Umbreit, Mark 1980. "Danish Use of Prisons and Community Alternatives," Federal probation, 44, 24-28.

Van Alstyne, D. J. and M. R. Gottfredson 1978. "A Multidimensional Contingency Table Analysis of Parole Outcome," Journal of Research in Crime and Del inquency, 15, 172-193.

Van West, A. 1964. "Cultural Background and Treatment of the Persistent offender," Federal probation, 28, 17-19.

Vold, George B. 1935. "Prediction Methods Applied to Problems of Classification Within Institutions," Journal of Criminal Law and Criminology, 25, $202-209 .$,

Wainer, H. and Anne M. B. Morgan 1982. "Robust Estimation of Parole Outcome," Journal of Research in Crime and Delinguency, 19, 83-109.

Warren, M. Q. Community Treatment Project: An Evaluation of Community Treatment for Delinquents. Fifth Progess Report, Sacramento: California Youth Authority and NIMH, CTP Research Report No. VII, August 1968.

Wilson, James O. and Barbara Boland 1976. "Crime", The Urban Predicament, Washington, D.C.: The Urban Institute. 
APPENDIX A

INFORMATION CATEGORIES: VARIABLES AND VALUES

RECIDIVIST ACTIVITY

1. Forest Camp Probation Revocation

$$
\begin{aligned}
& 1=\text { Yes } \\
& \emptyset=\text { No }
\end{aligned}
$$

2. Number of arrests since Forest Camp

3. Number of convictions since Forest Camp

4. Number of probations since Forest Camp

5. Number revocations since Forest Camp

6. Number jail terms greater than 6 months

7. Number jail terms 6 months or less

8. Number months elapsed since last conviction

9. Most serious conviction

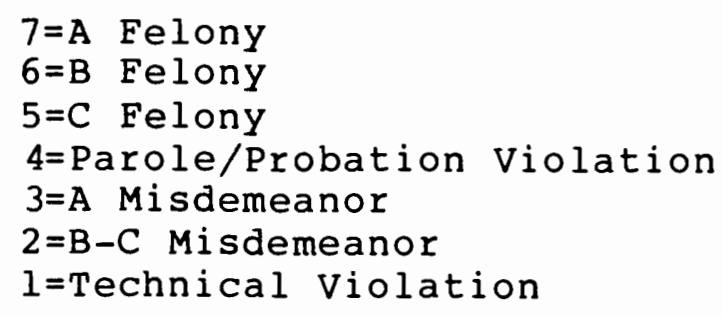


APPENDIX A (Cont.)

INFORMATION CATEGORIES: VARIABLES AND VALUES

PERSONAL INFORMATION

1. Race

$$
\begin{aligned}
& 1=\text { White } \\
& 2=\text { Non white }
\end{aligned}
$$

2. Age

3. Occupation Level

l=Skilled

2=Unskilled

4. Employment Time of Camp

$$
\begin{aligned}
& I=\text { Employed } \\
& \emptyset=\text { Unemployed }
\end{aligned}
$$

5. Drug Use

$$
\begin{aligned}
& \emptyset=\text { None } \\
& 1=\text { Mari juana } \\
& 2=\text { Barbi turates } \\
& 3=\text { Heroin } \\
& 4=\text { Heroin and another drug }
\end{aligned}
$$

6. Alcohol Dependent

$$
\begin{aligned}
& b=\text { No } \\
& l=\text { Yes }
\end{aligned}
$$

7. Personality Disorder

$$
\begin{aligned}
& \emptyset=\text { None } \\
& 1=\text { Yes } \\
& 2=\text { Subnormal IQ }
\end{aligned}
$$

8. Marital Status

$$
\begin{aligned}
& 1=\text { Single } \\
& 2=\text { Married } \\
& 3=\text { Di vorced }
\end{aligned}
$$

9. Living Arrangements

$$
\begin{aligned}
& 1=\text { Alone } \\
& 2=\text { Friends or lover } \\
& 3=\text { Parents } \\
& 4=\text { Wife }
\end{aligned}
$$

10. Parents Economic Status

$$
\begin{aligned}
& 1=\text { Comfortable } \\
& 2=\text { Fair } \\
& 3=\text { Marginal } \\
& 4=\text { Welfare }
\end{aligned}
$$

11. Parents Marital Status

$1=$ Mar $\mathrm{r}$ ied

$2=$ Wi dowed

3=Divorced

12. Age at First Arrest

13. Number Arrests Before Camp

14. Number Convictions

15. Work Record at Camp

$$
\begin{aligned}
& 1=\text { Excellent, very good } \\
& 2=\text { Good } \\
& 3=\text { Satisfactory } \\
& 4=\text { Poor }
\end{aligned}
$$

16. Level of Camp offense

$7=\mathrm{A}$ Felony

$6=\mathrm{B}$ Felony

$5=\mathrm{C}$ Felony

$4=$ Parole/Probation Violation

$3=A$ Misdemeanor

$2=B-C$ Misdemeanor

$\mathrm{I}=$ Tech Violation 
APPENDIX A (Cont.)

INFORMATION CATEGORIES: VARIABLES AND VALUES

\section{PERSONAL INFORMATION (Cont.)}

Type of Camp Offense

$I=I l$ legal possession of narcotics

$2=$ Technical parole violation, bail jump, criminal mischief $3=$ Unauthorized use of motor vehicle

$4=$ Criminal activity in drugs, illegal sale of narcotics

$5=$ Crimes against property (all burglaries and thefts)

$6=$ Crimes against a person

$7=0$ ther

Note:

For purposes of multivariate statistical analysis, the following variables were converted to dichotomous measures:

Personality Disorder

$$
\begin{aligned}
& \emptyset=\text { None } \\
& l=\text { Yes }
\end{aligned}
$$

Marital Status

$\emptyset=$ Not married

$1=$ Married 